\title{
The dictatorship of plagiarism and the obsession with quotations
}

\author{
Marcelo Krokoscz ${ }^{1}$
}

In recent years, plagiarism has become a concern in the national academic realm, although internationally this subject has been debated for decades. Considering some of these aspects may be important not to repeat mistakes already made and overcome in relation to plagiarism and at the same time represent an opportunity to deal with the problem at a national level from what is already consolidated globally. In this sense, the aim of this text is to present some of these perspectives without intending to indicate immediate solutions to exterminate plagiarism, but rather contribute to a debate on the subject.

Initially it is important to recognize that there are agreed standards that require the recognition of the sources used. If these guidelines are not followed, the practice of plagiarism is committed, that is, the use or misappropriation of content, ideas or other people's work. It turns out that this has not always been like this. The theoretical and conceptual basis that establishes the parameters of credit attribution derives from one of the first copyright laws that was enacted in England in 1710, which created the modern idea of the author as someone who owns a piece of work. This law was a late alternative related to the production in scale enabled by the advent of printing, which aimed to protect the author's financial interests. So, in this sense, indicating the authorship of a source means "giving credit" to the author who is the owner of what is being used ${ }^{(1)}$.

However, from the academic standpoint, why is it that we cite an author or a particular source? When Michel Foucault discussed this idea, he focused on the exploration of the notion of "establishment of discourse" to argue that the name of an author of a text plays a role in characterizing the specificity of a speech. Thus, it is conceivable that in a scientific text the citation of an author plays an allusive role, which aims to certify the arguments presented because it is based on ideas or results methodologically proven as the canon of science establishes. This means that, besides the property that someone can have of a text, a citation in the scientific field plays the role of guaranteeing argumentative reliability based on the propriety with which someone said something ${ }^{(2)}$. Thus, citing is not simply assigning credit, but validating propositions!

Moreover, despite the changes raised by the new technologies of information and communication, which massified and accelerated the production processes, sharing and exchanging of knowledge, one still insists on maintaining the romantic notion of the author as a subject who has exclusivity on certain knowledge, a conviction that is no longer so unshakable. It happens that with the advent of communication networks and of the information society the status of the nature of knowledge has been getting new approaches. One of them, for example, assumes that knowledge is not a commodity that is part of the exclusive property of someone. On the contrary, the more knowledge is shared, the better it is considered and, inversely, knowledge that does not impact seem minor but it is not always negligible ${ }^{(3)}$. In this perspective, knowledge is a public good, whose sole purpose is human development. Among its most immediate implications, one can consider aspects related to collective knowledge production, copyright decentralization, open access and sharing. Such findings have led to new thinking about what actually characterizes the authoring (creation) and plagiarism (reproduction), despite the fact that the debate that still draws the attention of the academic community is more related to the

${ }^{1}$ Fundação Escola de Comércio Álvares Penteado. São Paulo, SP, Brazil.

Corresponding author: Marcelo Krokoscz

Av. Liberdade, 532 - Liberdade. CEP: 01502-001 - São Paulo, SP, Brazil. Email: marcelok@fecap.br

Rev Rene. 2014 July-Aug; 15(4):557-8 
conservation of old assumptions than to the necessary transformation and conceptual improvement ${ }^{(4)}$.

The introduction of these ideas in the discussion in a way aims at promoting trivialization of the reproducibility of knowledge. The scientific originality is one of the conditions for the advancement of knowledge and the authorial fraud is a practice that continues to be a demand that requires confrontation. However, deepening of thinking and conceptual improvement related to copyright processes are imposed as essential conditions and requirements nowadays, otherwise one runs the risk of keeping in the academic realm intransigent positions that see plagiarism in everything due to insufficient or improper use of quotations. In other words, this can become a dictatorship of plagiarism and an obsession with quotations that hinder rather than help improve the quality of textual scientific production.

\section{References}

1. Chartier R. A ordem dos livros: leitores, autores e bibliotecas na Europa entre os séculos XIV e XVII. Brasília: Universidade de Brasília; 1999.

2. Rose M. Authors and owners: the invention of copyright. Cambridge: Harvard University Press; 1993.

3. Hess C, Ostrom E. Understanding knowledge as a commons: from theory to practice. Cambridge: MIT Press; 2007.

4. Marsh B. Plagiarism: alchemy and remedy in higher education. Albany: State University of New York Press; 2007. 